\title{
The positive tuberculin test is not synonymous with latent tuberculosis
}

\author{
Bocanegra-Román $\mathrm{N}^{1}$, Verdeguer-Abad A ${ }^{1}$, Osada J ${ }^{2}$ \\ ${ }^{1}$ Student of Medicine. Faculty of Health Sciences. Universidad Científica del Sur. Lima. Peru. \\ ${ }^{2}$ Epidemiologist. Faculty of Health Sciences. Universidad Científica del Sur. Lima. Peru.
}

To the editor,

We read with great interest the article titled "Prevalence and predictive factors of latent tuberculosis infection in a Spanish prison", published in your journal as part of the first edition of $2018^{1}$. Although the results are very important and the discussion is extremely relevant, the methodology used means that they did not necessarily reflect the real situation in such institutions.

A negative tuberculin test on Spaniards at the prison in question does not rule out latent tuberculosis infection (LTBI), due to the large number of false negatives. In other words, a positive test may indicate that an individual has a latent infection or an infection from non-tuberculosis microbacteria, it may also be the case that the person was vaccinated with the Bacille Calmette and Guérin (BCG) vaccine, in the case of individuals who are not sensitive to Mycobacterium tuberculosis, but who received blood transfusions from sensitised persons, along with individuals who live in endemic zones ${ }^{2}$. On the other hand, a negative purified protein derivative (PPD) test does not necessarily exclude the possibility of infection or of the disease itself. The belief is that approximately 10\% of sick immunocompetent children with tuberculosis (TBC) have non-reactive PPD, in the same way that other immunosupression factors also produce false negatives, such as infection by the human immunodeficiency virus (HIV), immunosuppressive agents, viral infections such as chickenpox or mumps, malnutrition, acute or disseminated TBC, or even old age. Another common cause for a false negative in this test is caused by the technique used in this test. A possible failure in the PPD cold chain caused by exposure to light or heat, subcutaneous injection, the use of expired PPD, or an incorrect reading (the reader is not duly trained or makes the reading before or after the established time interval) will lead to errors when interpreting the test ${ }^{3}$.

We would recommend the use of more sensitive and specific tests to detect LTBI, such as the interferon gamma release assays (IGRAS), using serum tests such as QuantiFERON TB Gold In-Tube (QFTGIT) or the T-SPOT TB, which directly detects the production of interferon gamma by mononuclear cells exposed to peptides similar the antigens of $\mathrm{Myco-}$ bacterium tuberculosis. These assays are more specific than the tuberculin test, especially for persons vaccinated with the BCG ${ }^{4}$.

We would also recommend taking into account other risk factors for contracting LTBI, such as overcrowding, poor ventilation, unhygienic conditions and food that is both scarce and provides little nutrition, as well as the illegal consumption of alcohol, drugs and sexual relations, which may be with or without consent. All these risk factors exercise an influence on infectious diseases, including tuberculosis ${ }^{5}$.

We acknowledge the effort made by the authors to research an issue that is so important but which has been so little studied; and for this very reason we call on other authors to continue investigating in this field, and for them to use the best tools to evaluate the results that will enable them to obtain more precise and reliable conclusions.

\section{CORRESPONDENCE}

Alejandra Verdeguer Abad

Universidad Científica del Sur. Lima, Perú

E-mail: aleverdeguer@gmail.com 


\section{REFERENCES}

1. López de Goicoechea-Saiz ME, Sternberg F, PortillaSogorb J. Prevalencia y factores predictores de infección tuberculosa latente en un centro penitenciario tipo español. Rev Esp Sanid Penit. 2018;20:4-10.

2. Sidibe A, Matteelli A, Menzies R, Getahun H. Differences in BCG vaccination and tuberculin skintest positivity. Global Tuberculosis Programme, World Health Organization, Geneva 1211, Switzerland. Lancet Infect Dis. 2015;15:1003.

3. Torres Z, Pickett V, Herrera T. Técnica de la reacción de tuberculina (P.P.D.). Programa Na- cional de Control y Eliminación de la Tuberculosis. Ministerio de Salud. Santiago de Chile; 2017.

4. Cascante JA, Pascal I, Eguía VM, Hueto J. Diagnóstico de la infección tuberculosa. Anales Sis San Navarra. [Internet]. 2007 [citado 21 Sep 2018];30: 49-65. Disponible en: http://scielo.isciii. es/scielo.php?script=sci_arttext\&pid=S1137$66272007000400005 \& \operatorname{lng}=\mathrm{es}$

5. LoBue PA, Castro KG. Is It Time to Replace the Tuberculin Skin Test With a Blood Test? JAMA. 2012;308:241-2. 